\title{
The Influence of Leadership Style on Telecommuters in the Insurance Industry: A Contingency Theory Approach
}

\author{
Paul E. Madlock \\ Southeast Missouri State University
}

This study examining how telecommutes' in the insurance industry view their supervisor's leadership style and how this determination influences the employee's perceptions of their supervisor's communication competence and their communication satisfaction with their supervisor, as well as their own job satisfaction and organizational commitment. The study applied Contingency Theory as a theoretical underpinning. The results indicated that for supervisors to be perceived as leaders they must effectively communicate task related information more than relational oriented messages. These findings add to research by identifying situations in which leaders are to behave in a fashion unique to the computer mediated work setting.

\section{INTRODUCTION}

The work landscape has changed dramatically because of the influx of technology, which has given rise to new work structures such as telecommuting, also known as telework and virtual work (Nickson \& Siddons, 2004). Telecommuting is an alternative work arrangement in which employees perform tasks from someplace other that are normally done in a primary or central workplace, for at least some portion of their work schedule, using electronic media to interact with others inside and outside the organization (Baruch, 2001). The telecommuting work setting allows employees to conduct their work from home which allows employees to adjust their schedule to meet household needs and family demands or to save commuting costs (Nickson \& Siddons, 2004). In other words, telecommuting is becoming increasingly common in organizations, especially as a means of helping employees improve work-family relationships.

This flexible work arrangement has reported estimates suggesting that more than $11 \%$ of the U.S. workforce is engaged in telework and that worldwide, the growth of telecommuting is occurring by upwards of $30 \%$ per year (World at Work, 2009). A number of organizations are utilizing this new work structure to better service customers and to save money from office space that would have otherwise used for employees (Baruch, 2001). One organization that is of interest here that regularly utilizes telecommuters is the insurance industry.

The U.S. insurance market had total gross written premiums of $\$ 1,371.6$ billion in 2015 , representing a compound annual growth rate (CAGR) of $2.9 \%$ between 2011 and 2015 and is expected to reach the value of $\$ 1,447.8$ billion by the end of 2016 ; thus, making the insurance industry one of the largest industries in the U.S. (MarketLine, 2016). Further, because of the influx of technology into today's workplace, the insurance industry has become one of the largest to utilize telecommuters (Shaw, 1996). In 
the insurance industry, not only are telecommuters saving companies money by reducing the costs associated with office space, they are providing customers with improved service. For example, Progressive Insurance Group, Mayfield Heights, Ohio, and more recent, State Farm Insurance Company implemented an immediate response program under which automobile claims adjusters, working out of vans containing computers, fax machines and cellular telephones, respond immediately to all accidents and process the claim on the spot. This includes, not only the collection of information but also payment and arrangements for the customer. Additionally, if the claims adjuster has an immediate question related to the on the spot processing of a claim, his or her supervisor is only a call or a few keystrokes away from addressing the question. Progressive and State Farm is using this program to not only improve its position in its current markets but to expand into new markets. Here the virtual office is a van. Thus, a focus on telecommuting in the insurance industry appears to be warranted.

One area involving telecommuting that has received little attention by researchers thus far involves the ability of supervisors to lead telecommuters in the insurance industry through technology. We do know that leadership is enacted through communication and that it can be divided into the content (task) and the presentation (relational) of messages (Holladay \& Coombs, 1993). We also know that in traditional brick and mortar businesses that relationship-oriented leadership is displayed more frequently, preferred more often, and has a greater impact on employees' communication and job satisfaction than does task oriented leadership (Madlock, 2008). However, research has been mixed regarding the ability of computer technology to effectively communicate nonverbal nuances found in face to face (FtF) interactions such as tone of voice or facial expressions deemed important in relational development (see Kiesler, Siegel, \& McGuire, 1987). Therefore, since communication mediated through technology is different from $\mathrm{FtF}$ interactions and that $\mathrm{FtF}$ interactions are no longer considered to be the standard by which to measure all other forms of communication it is likely that leadership in the virtual workplace will differ from the traditional FtF work environment. As a result, the goal of this study was to examine how insurance workers who telecommute view their supervisor's leadership style and how this determination influences the employee's perceptions of their supervisor's communication competence and their communication satisfaction with their supervisor, as well as their own job satisfaction and organizational commitment. To better understand the leadership style of supervisors in the insurance industry and the way in which they communicate with subordinates through technology, a contingency approach to leadership will provide a theoretical underpinning for the current study and will be discussed in greater detail below.

\section{REVIEW OF LITERATURE}

\section{Theoretical Background}

Contingency theory suggests that there is not a single best way to manage processes of organizing, decision-making, and leadership since different environments provide different antecedents (Fiedler, 1964). For instance, organizational behaviors (such as leadership) are contingent on differing environments, including internal and external contexts (Waterhouse \& Tiessen, 1978). Prior contingency theory models indicate how technology impacts the communication requirements of organizational units. More specifically, these models focused on the way information is communicated and attempt to describe how organizations can match different technologies (e.g., use of cell phones or computers to communicate with supervisors) to structures (e.g., telecommuting) to accomplish high performance (Cohen \& Levinthal, 1990; Nadler \& Tushman, 1988) The basic notion of these models is that a proper fit between the complexity and use of a technology and the structures of an organization (e.g., claims adjusters as telecommuters) will yield high unit performance (e.g., profits and satisfied customers).

Therefore, contingency theory forms a natural theoretical basis for explaining the circumstances under which insurance companies take part in telecommuting and why leadership is contingent on internal and external environments. For example, internal factors such as the ability to accurately and efficiently process customer claims coupled with the external factors of satisfied customers through expeditious claims processing indicates that telecommuting is an appropriate work setting. Further, working from a 
remote location such as a van, allows claims adjustors to provide customers with rapid response and in turn, the claims adjusters need the rapid response from supervisors when on the spot information is needed. Thus, leadership is contingent on internal environments, the use of and management of telecommuters and by external environmental needs, such as the clarification of a process or an answer to a question by telecommuters. Based on the nature of the work, coupled with the communication needs of telecommuters in the insurance industry, a contingent style of leadership is necessary. Therefore, the leadership style of supervisors in the realm of telecommuting will be discussed in greater detail.

\section{Leadership Style}

As organizations and employees become increasingly dispersed, communication has become the principal means by which individuals lead others (Penley \& Hawkins, 1985) in other words, "leadership is enacted through communication" (Barge 1994, p. 21). Castaneda and Nahavandi (1991) added that employees are most satisfied when they perceive their leaders to be communicating both task and relational oriented behaviors. A conceptualization of leadership that is comprised of task and relational behaviors is the styles approach. The Ohio State and the Michigan studies were strong early representatives of the styles approach. The Ohio State studies (Hemphill \& Coons, 1957) identified two types of leadership behaviors; which were to provide structure and to nurture subordinates, whereas, the Michigan studies (Cartwrite \& Zander, 1960; Likert, 1961) identified leadership behaviors to contain employee-oriented and production- oriented behaviors. Prior research has examined the effects of leadership style in relation to effective communication skills (Fairhurst, 1993; Mintzberg, 1994), interpersonal communication (Quick \& Macik-Frey, 2004), and rapport building (Campbell, White, \& Johnson, 2003).

To date, research has yet to fully examine the leadership style of those who supervise telecommuters in the insurance industry, especially through the lens of contingency theory. Leadership may be among the most compelling factors that influence the adoption of telecommuting and the work attitudes and behaviors of telecommuters (Wang \& Walumbwa, 2007). Research indicates that managers are uncomfortable with being responsible for a team if they are not able to be in FtF contact with those members (Topi, 2004). Yukl (2002) found that in the case of telecommuting, managerial effectiveness was associated with influencing people and developing a greater commitment to communicating task related objectives. More recently, Madlock (2012) indicated that in the realm of telecommuting, employees preferred and were more satisfied with supervisors who communicated task oriented leadership rather than relational oriented leadership. Further, Madlock (2013) examined Motivating Language Theory (Sullivan, 1988) in the realm of telecommuting and found that supervisors of telecommuters tended to use the motivating language of direction giving (task oriented) most frequently followed by empathetic (relational oriented) and to a far lesser degree, meaning-making language (organizational related communication). Direction giving language was also indicated as the greatest predictor of communication and organizational outcomes.

As a result of a combination of prior research and contingency theory, it could be extrapolated that the leadership style of those who supervise telecommuters in the insurance industry is contingent on internal and external environments/structures. Further, based on the requisite to fulfill the needs of policy holders with expeditious claims processing, coupled with the need for clear task related communication between insurance agents and their supervisors, especially in a time of crisis; it is reasoned here that supervisors of telecommuters in the insurance industry will display greater task than relational oriented leadership. Therefore, the following hypothesis was advanced:

H1: Telecommuters in the insurance industry will perceive their supervisors as displaying greater task-oriented leadership than relational oriented leadership.

Prior research (see Madlock, 2012) examining telecommuting found a connection between a supervisor's leadership style and their communication competence. Specifically, Madlock (2012) found a relationship between the task leadership style of supervisors and their perceived communication competence. However, the link between leadership style and communication competence in the realm of 
telecommuting, especially in the insurance industry, has yet to be established; therefore, communication competence was included in this study.

\section{Communication Competence}

Spitzberg and Cupach (1981) conceptualized communication competence "as a form of interpersonal influence, in which an individual is faced with the task of fulfilling communication goals (effectiveness) while maintaining conversational and interpersonal norms (appropriateness)" (p. 1). According to Pondy (1978), through interpersonal communication a leader can help followers understand why and how the activities they engage in are meaningful. Although there is an acknowledgement that leadership and communication are conceptually related, there has been little research explicitly examining leader communication effectiveness (Westley \& Mintzberg, 1991). In a similar vein, there appears to be limited research directly examining the relationship between the communication competence of supervisors and their leadership styles. However, one such study was that of Madlock (2008) who found that supervisors who engaged in a relational leadership style were viewed as more competent communicators than those supervisors who engaged in a task oriented leadership style. Unlike the focus of the current study, the aforementioned study was situated in traditional brick and mortar workplaces where FtF communication interactions prevailed. Another area that has a scant amount of research to date involves the communication competence of supervisors in the technologically mediated realm; specifically telecommuting in the insurance industry. Given the limitations in prior research coupled with the pressures from external and internal environments (as mentioned in contingency theory) associated with telecommuting in the insurance industry, the following hypothesis was advanced:

H2: In the realm of telecommuting in the insurance industry, a supervisor's task oriented leadership style will be a greater predictor of that supervisor's communication competence than will his or her relational oriented leadership style.

In the telecommuting setting, there also appears to be a gap in the research examining supervisor task and relational oriented leadership and employee outcomes such as communication satisfaction. Due to the significance of communication to organizational life (Deetz, 2001), the consideration of communication satisfaction has important implications here in the realm of telecommuting. As a result, communication satisfaction was considered here and will be discussed in greater detail below.

\section{Communication Satisfaction}

The communication satisfaction of employees is a measure of how well the "available information fulfills the individual's requests for information pertaining to the task-role or for simply being about organizational activities" (Putti, Aryee, \& Phua, 1990, p. 45). Further, prior research has shown communication satisfaction to be related to a number of important work relationships, such as, supervisor/subordinate relationships (Mueller \& Lee, 2002), and employees who experience low levels of communication satisfaction report reduced commitment, greater absenteeism and turnover, increased industrial unrest, and reduced productivity (Hargie, Tourish, \& Wilson, 2002).

More recent research involving communication satisfaction indicated an association between supervisor leadership style and the communication satisfaction of their subordinates, with relational oriented leadership having a greater positive impact on the communication satisfaction of subordinates than did task oriented leadership (Madlock, 2008). Given the technological focus of the current study it is reasoned here that the outcomes associated with the leadership style and the communication competence of supervisors in the telecommuting environment may differ from those found in traditional work settings. Therefore, the following research question was advanced:

RQ1: Which behavior displayed by supervisors of telecommuters in the insurance industry, task leadership style, relational leadership style, or communication competence, will serve as the greatest predictor of their telecommuters' communication satisfaction?

Although communication satisfaction has been found to be significantly related to job satisfaction (Pincus, 1986), job satisfaction and communication satisfaction have been found to be distinct constructs (Gregson, 1991). Companies who have embraced telecommuting look at it as a program to help attract 
and retain employees, so that these employees remain satisfied with their jobs and stay with the company. Many positive outcomes related to telecommuting have been claimed in the literature, the most often cited is job satisfaction (Pinsonneault \& Boisvert, 2001). Surprisingly, despite telecommuting's growing popularity, there is limited evidence to support this link with job satisfaction and even less with organizational commitment. Therefore, the job satisfaction and organizational commitment were included here.

\section{Job Satisfaction and Organizational Commitment}

Job satisfaction has been defined in a number of ways, such as: "a pleasurable or positive emotional state resulting from the appraisal of one's job or job experiences" (Locke, 1976, p.

1297); the degree of enjoyment workers receive from their job (Spector, 1985), and the positive evaluation of the interpersonal relationships between employees and management (Kenny \& Cooper, 2003). Conversely, a reduction in interpersonal communication between workers can negatively impact job satisfaction and organizational commitment (Korte \& Wynne, 1996). A worker that is satisfied with his or her job, enjoys life, displays positive actions, is psychology healthy, and is seen as having success in both business and private life (Demirel, 2014). To the contrary, workers who are not satisfied with their jobs may experience feelings that cause them to distance themselves from their jobs and express hopelessness about the future (Sageer, Rafat, \& Agarwal, 2012).

Research involving the antecedents to the job satisfaction in the realm of telecommuting has been mixed. Some research indicates that telecommuters experience job satisfaction from the nature of the work such as increased autonomy and flexibility associated from working from home (Feldman \& Gainey, 1997). Contrary research suggests that telecommuters experience reduced job satisfaction due to feelings of disconnect with others in the organization, limitations with communication, and feelings of being out of the loop (Bailey \& Kurland, 2002; Cooper \& Kurland, 2002). In line with contingency theory, maybe job satisfaction in the realm of telecommuting is associated with finding the right balance to achieve optimum results (Golden, 2006). Perhaps, the appropriate leadership style associated with the need for immediate task related information as required in the insurance industry, would contribute to the job satisfaction of telecommuters.

While more research is needed, these prior findings demonstrate some of the implications associated with telecommuting. Specific to the current study, there has been little prior research examining the association between a supervisor's leadership style and the job satisfaction of telecommuters; therefore, the following hypothesis and research question was offered:

H3: There will be a positive relationship between both task and relational leadership style and a telecommuter's job satisfaction.

RQ2: Which behavior displayed by a supervisor, task leadership, relational leadership, or communication competence, will serve as the greatest predictor of a telecommuter's job satisfaction?

Organizational commitment is characterized by a strong belief in and acceptance of the organization's goals and values, a willingness to exert considerable effort for the organization, and a desire to retain membership in the organization (Sager \& Johnston, 1989). Specific to telecommuting, literature suggests that telecommuting may alter how telecommuters feel about their identification with the organization due to their physical distance and limited communication with co-workers and supervisors (Thatcher \& Zhu, 2006). Further, telecommuting alters the social and psychological ties that bind telecommuters to the organization, and the affiliation they feel toward the organization (Thatcher \& Zhu, 2006). As research suggests, telecommuters experience fewer socio-emotional cues during interactions with others combined with few physical reminders of their belonging to the organization experience weaker ties to the organization and its members than employees in traditional brick and mortar organizations (Wiesenfeld, Raghuram, \& Garud, 2001). The study of telecommuting involves not only the job and those who telecommute but also the broader context of coworker and supervisor relationships (Ting, 1997). Further, Ting (1997) notes that much of the satisfaction and commitment of telecommuters may be associated with 
the satisfaction derived from these communication interactions. Therefore, the following hypotheses and research question were advanced:

H4: There will be a positive relationship between both task and relational leadership style and a telecommuter's organizational commitment.

RQ3: Which behavior displayed by a supervisor, task leadership, relational leadership, or communication competence, will serve as the greatest predictor of a telecommuter's organizational commitment?

\section{METHOD}

\section{Participants}

Participants were comprised of 222 telecommuters $(47.7 \%$ female, $\mathrm{n}=106)$ and $(52.3 \%$ male, $\mathrm{n}=$ 116), whose overall tenure at their current job ranged from 3 to 12 years $(\mathrm{M}=7.65, \mathrm{SD}=3.27)$, and age ranged from 23 to $49(\mathrm{M}=30.86, \mathrm{SD}=6.59)$. Also, the positions of the telecommuters who participated included (89\% claims processors/adjustors; $10 \%$ customer service representatives; $1 \%$ other). Of the technology used, all the participants reported using a combination of technologies when communicating with their supervisors. These technologies included the most frequently reported form being cell phones $(68 \%)$ and by laptop computers/tablets $(32 \%)$. The most prevalent forms of communication used were phone calls (primarily via cell phone), followed by instant messages (IM), text message, email, and video calls (e.g., Face time).

\section{Procedures}

The data collection procedure followed that of (Hartman, Stoner, \& Arora, 1991). Based upon a review of the telecommuting literature organizations in the insurance industry believed to have telecommuting programs were contacted by the author for possible participation in this study. Of the organizations contacted, two insurance companies agreed to participate in the first of two data collections and two insurance companies in the second data collection. Two data collections were conducted because the first distribution only yielded 122 useable surveys and a second distribution was then added that yielded 100 additional useable surveys. Participants included full-time non-management employees working for insurance companies with established telecommuting programs in which employees worked from a remote location using technology (i.e., telecommuters) to conduct business and communicate with their supervisors. The organizations that agreed to participate in the study either distributed copies of the questionnaire, allowed the author to distribute copies of the questionnaire, or made copies of the questionnaire available to employees on a volunteer basis. Respondents mailed completed questionnaires to the author. Based on distributions of questionnaires and on reports from site managers, approximately 500 telecommuters (300 in the first distribution and 200 in the second) were invited to participate in the study; 222 telecommuters (approximately 44.4\%) provided useable completed surveys.

\section{Measures}

Leadership style was measured by the 20-item Leadership Style Questionnaire developed by Northouse (2001). The instrument measures the task and relational leadership styles and, when summed, represents a general leadership profile. A 5-point Likert-type scale $(1=$ strongly disagree to $5=$ strongly agree) was used in the study. Prior research reported scale reliability of .95 (Madlock, 2008). Cronbach's alpha for the current study found that task leadership style was $.90(\mathrm{M}=40.97, \mathrm{SD}=5.65)$, and relational leadership style was $.91(\mathrm{M}=23.65, \mathrm{SD}=5.27)$.

Communication competence was measured by the 12-item Communicator Competence Questionnaire developed by Monge, Backman, Dillard, and Eisenburg (1982). The items were measured on a 5-point Likert-type scale ranging from $(1=$ strongly disagree to $5=$ strongly agree $)$. Prior research reported scale reliability of .93 (Madlock, 2006). Cronbach's alpha for the current study was $.91(\mathrm{M}=34.35, \mathrm{SD}=$ 4.92). 
Communication satisfaction was measured with the 19-item Interpersonal Communication Satisfaction Inventory (ICSI) developed by Hecht (1978). A 7-point Likert scale $(1=$ strongly disagree to $7=$ strongly agree) was used. A slight modification was made to the original scale with a lead in sentence (When communicating with my coworkers I feel...) preceding each statement. Prior studies reported reliabilities ranging from .72 to .93 and strong validity (Rubin, Palmgreen, \& Sypher, 1994). Cronbach's alpha for the current study was $.90(\mathrm{M}=66.27, \mathrm{SD}=10.22)$.

Job satisfaction was measured by the eight-item Abridged Job In General Scale (AJIG) (Russell, Spitzmüller, Lin, Stanton, Smith, \& Ironson, 2004). A 5-point Likert-type response format (1 = strongly disagree to $5=$ strongly agree) was used in the current study instead of the original scale formatting (i.e., using 0 for "no," 1 for "?" and 3 for "yes) to be consistent with other parts of the questionnaire. The scale is comprised of single word or short statements regarding an employee's overall perception of their job (e.g., Good, Better than most, Undesirable). Prior research indicated that the AJIG Scale had strong reliability with a Cronbach's coefficient alpha of .90 (Madlock, 2012). Cronbach's alpha for the current study was $.84(\mathrm{M}=26.23, \mathrm{SD}=4.82)$.

Organizational commitment was measured with the 15-item Organizational Commitment Questionnaire (OCQ) (Mowday, Steers, \& Porter, 1979). The items were measured on a 7-point Likert scale ranging from $1=$ strongly disagree to $7=$ strongly agree. The scale is intended to measure employee attachment to the organization, for example, "I am proud to tell others that I am part of the organization". Prior research, e.g., Madlock (2006) indicated scale reliability of .93. Cronbach's alpha for the current study was $.89(\mathrm{M}=41.15, \mathrm{SD}=9.02)$.

\section{RESULTS}

Hypothesis 1 predicted that telecommuters would perceive their supervisors as displaying greater task-oriented leadership than relational oriented leadership. Results indicated that supervisors engaged in greater task-oriented leadership $(M=40.97, S D=5.65)$ than they engaged in relational oriented leadership behaviors $(M=23.65, S D=5.27)$. Therefore, the hypothesis was supported.

Hypothesis 2 predicted that the task-oriented leadership style of supervisors would be a greater predictor of their communication competence than would their relational oriented leadership style in a telecommuting work environment. Using multiple regression, supervisor communication competence was regressed on a linear combination of the two predictor variables. Results indicated that the task oriented leadership style of supervisors accounted for $R 2=.11(11 \%)$ of the variance in their perceived communication competence, $F(1,220)=17.37, p<.001$, whereas the equation containing both the task and relational oriented leadership style of supervisors accounted for $R 2=.16(16 \%)$ of the variance in the perceived communication competence of supervisors, $F(2,219)=15.20, p<.001$. Supervisors' taskoriented leadership style was found to be the greater predictor of their perceived communication competence, $\beta=.33, p<.001$ than was their relational oriented leadership style $\beta=.21, p<.001$.

Hypothesis 3 predicted there would be a positive relationship between both task and relational leadership style of supervisors and the job satisfaction of telecommuters. Results of Pearson's correlational analysis showed that the data were consistent with the hypothesis by indicating a significant positive relationship between the variables. Specifically, a strong relationship was indicated between telecommuters' job satisfaction and their supervisor's task-oriented leadership style $(r=.68, p<.01)$, whereas a weak relationship was indicated between the job satisfaction of telecommuters and their supervisor's relational oriented leadership style $(r=.21, p<.01)$ (see Table 1 for all the correlational results). 
TABLE 1

MEANS, STANDARD DEVIATIONS, AND CORRELATIONS AMONG STUDY VARIABLES

\begin{tabular}{|l|l|l|l|l|l|l|}
\hline & 1 & 2 & 3 & 4 & 5 & 6 \\
\hline 1. Task Leadership & --- & & & & & \\
\hline 2. Relational Leadership & .14 & --- & & & & \\
\hline 3. Job Satisfaction & $.68^{* *}$ & $.21^{* *}$ & --- & & & \\
\hline 4. Communication Satisfaction & $.57^{* *}$ & $.19^{*}$ & $.48^{* *}$ & --- & & \\
\hline 5. Communication Competence & $.32^{* *}$ & $.18^{*}$ & $.43^{* *}$ & $.23^{* *}$ & --- & \\
\hline 6. Organizational Commitment & $.46^{* *}$ & $.18^{*}$ & $.31^{* *}$ & $.20^{*}$ & $.37^{* *}$ & --- \\
\hline Note: ${ }^{* *}$ statistically significant at $\mathrm{p}<.001, *$ statistically significant at $\mathrm{p}<.01$ \\
\hline
\end{tabular}

Hypothesis 4 predicted there would be a positive relationship between both the task and relational oriented leadership style of supervisors and the organizational commitment of their telecommuters. Results of Pearson's correlational analysis showed that the data were consistent with the hypothesis by indicating a significant positive relationship between the variables.

Specifically, a strong relationship was indicated between telecommuters' organizational commitment and their supervisor's task-oriented leadership style $(r=.46, p<.01)$, whereas a weak relationship was indicated between telecommuters' organizational commitment and their supervisor's relational oriented leadership style $(r=.20, p<.01)$.

Research question 1 sought to answer the question of which behavior displayed by a supervisor, taskoriented leadership, relational oriented leadership, or communication competence, would serve as the greatest predictor of a telecommuter's communication satisfaction? Using multiple regression, communication satisfaction was regressed on a linear combination of the three predictor variables. Results indicated that supervisor communication competence accounted for $R 2=.041(4.1 \%)$ of the variance in telecommuters' communication satisfaction, $F(1,220)=8.05, p<.01$, whereas the equation containing both communication competence and relational leadership style accounted for $R 2=.052(5.2 \%)$ of the variance in telecommuters' communication satisfaction, $F(2,219)=6.07, p<.01$. The addition of supervisor task oriented leadership style to the regression model accounted for $R 2=.35(35 \%)$ of the variance in telecommuters' communication satisfaction, $F(3,218)=28.24, p<.001$.

Supervisors' task-oriented leadership style was found to be the greatest predictor of telecommuter communication satisfaction, $\beta=.57, p<.001$, whereas communication competence and relational leadership style were not found to be a significant predictor of telecommuter communication satisfaction.

Research question 2 sought to answer the question of which behavior displayed by supervisors, task leadership, relational leadership, or communication competence, would serve as the greatest predictor of telecommuters' job satisfaction? Using multiple regression, job satisfaction was regressed on a linear combination of the three predictor variables. Results indicated that supervisor communication competence accounted for $R 2=.163(16.3 \%)$ of the variance in telecommuters' job satisfaction, $F(2,120)=36.53, p$ $<.001$, whereas the equation containing both supervisor communication competence and relational leadership style accounted for $R 2=.181(18.1 \%)$ of the variance in telecommuters' job satisfaction, $F(2$, $219)=20.25, p<.001$. The addition of supervisor task leadership style to the regression model accounted for $R 2=.483(48.3 \%)$ of the variance in telecommuters job satisfaction, $F(3,218)=52.61, p<.001$. Supervisors' task-oriented leadership style was found to be a greater predictor of telecommuter job satisfaction, $\beta=.59, p<.001$ than was supervisor communication competence $\beta=.22, p<.001$. Relational oriented leadership style was not found to be a significant predictor of telecommuter job satisfaction.

Research question 3 sought to answer the question of which behavior displayed by a supervisor, taskoriented leadership, relational oriented leadership, or communication competence, would serve as the greatest predictor of a telecommuter's organizational commitment? Results indicated that supervisor communication competence accounted for $R 2=.132(13.2 \%)$ of the variance in telecommuters' 
organizational commitment, $F(2,120)=27.57, p<.001$, whereas the equation containing both supervisor communication competence and relational leadership style accounted for $R 2=.139(13.9 \%)$ of the variance in telecommuters' organizational commitment, $F(2,219)=11.78, p<.001$. The addition of supervisor task leadership style to the regression model accounted for $R 2=.245(24.5 \%)$ of the variance in telecommuters' organizational commitment, $F(3,218)=17.93, p<.001$. Supervisors' task leadership style was found to be the greater predictor of telecommuter organizational commitment, $\beta=.34, p<.001$ than was supervisor communication competence $\beta=.22, p<.001$. Relational leadership style was not found to be a significant predictor of telecommuter organizational commitment.

\section{DISCUSSION}

The current study examined the insurance industry because it has become a leader in the adoption of telecommuting. The purpose was to extend prior research by examining how employees who telecommute in the insurance industry view their supervisor's leadership style (task and or relational) and how this determination influenced the employee's perceptions of their supervisor's communication competence; their communication satisfaction with their supervisor; their own job satisfaction and organizational commitment. Contingency theory formed a natural theoretical basis for explaining the circumstances under which insurance companies take part in telecommuting and why leadership is contingent on internal and external environments. It was indicated here that leadership was contingent on internal environments, the use of and management of telecommuters, and by external environmental needs, such as the clarification of a process or to answer a question from telecommuters. In other words, the leadership style of supervisors (task and or relational) was contingent on the supervisors rapid and accurate response to telecommuters when on-the-spot information was needed. Specifically, the findings indicated that leaders engaged in more task-oriented behaviors than relational. This finding supports the use of contingency theory because the external environment of telecommuting in the insurance industry required task related leadership to quickly address the needs of telecommuters. This finding appears to differ from prior leadership style research in traditional FtF work environments (see Madlock, 2008), where leaders primarily engaged in relational oriented leadership behaviors.

Another interesting finding of the current study centers on the communication competence of supervisors. It appears that telecommuters perceive supervisors who engage in a task-oriented leadership style to be more competent communicators than those supervisors who utilize relational oriented leadership behaviors. Again, this finding may be attributed to contingency theory in that the external environment of telecommuting in the insurance industry requires expeditious answers (task-oriented behaviors) to inquiries from telecommuters. Based on contingency theory, the environments associated with the insurance industry require a task-oriented leadership style. Therefore, it stands to reason that the assessment of a supervisor's communication competence by telecommuters in the insurance industry would be related to the supervisor's use of task-oriented leadership. More broadly put, perhaps the relationship between supervisors and subordinates in this technologically mediated environment lends itself to the exchange of task related information. Also, it could also be reasoned that task-oriented leadership is the expected form of communication by telecommuters in the insurance industry and communication competence may be associated with meeting these expectations. Further, it could be reasoned that communication competence may be contingent upon the environment and the association between communication competence and leadership style differs here from FTF environments (see Madlock, 2008). Not to discount the value of relational oriented leadership, but it seems that in the technologically mediated world of telecommuting, this style of leadership appears far less important than does task oriented leadership.

Additional findings of interest here were found in hypothesis three where task-oriented leadership style was found to be the greatest predictor of the communication satisfaction of telecommuters in the insurance industry. In line with contingency theory, this finding suggests that the communication satisfaction of telecommuters in the insurance industry is associated with their supervisor's ability to expeditiously communicate task relevant information when needed. 
The current study also indicated that the task-oriented leadership style of supervisors was the greatest predictor of the job satisfaction and organizational commitment of telecommuters in the insurance industry. It appears that providing telecommuters in the insurance environment with rapid task related information (task-oriented leadership) from supervisors has many value added outcomes beyond satisfied loyal customers (e.g., meeting the needs of customers with expeditious claims processing) to include satisfied and committed employees. Although, there are additional factors associated with the satisfaction and commitment of telecommuters, such as the autonomy of working from home, the current study added the task-oriented leadership style of supervisors.

In sum, the current findings are of value to insurance companies who currently utilize telecommuters and those who plan to adopt this structure in the future. A focus must be placed on the task related competencies of those who supervise telecommuters in the insurance industry.

It appears that telecommuters in the insurance industry contact their supervisors for rapid accurate task related information. For instance, from a claims adjuster's perspective, it is possible that the stress associated with needing an immediate answer to a question during a time of crisis is the most valued communication response from a supervisor. Therefore, supervisors in the insurance must be trained to effectively communicate task related knowledge to telecommuters through technology.

\section{Limitations}

Although the current study adds to our understanding of leadership and communication between supervisors and telecommuters in the insurance industry it is not without limitations. For example, since behaviors are not enacted in a vacuum, it would be remiss to simply consider these findings without considering their relationship with other variables such as the freedom of working from home, as mentioned previously, which may account for a great deal of the satisfaction felt by telecommuters. In other words, in order to fully understand the impact of these results a qualitative study may need to be considered in which the researcher can ask open ended questions to uncover nuances not found in a quantitative study. This information may prove to be of value and therefore, serves as a guide for future research.

Given the paucity of prior research examining leadership and technology in the insurance industry there are a number of future research directions that could be pursued. One possible direction centers on a dialogic approach to examine the specific communication interactions that take place between supervisors and subordinates in the telecommuting environment. This research direction may allow researchers to determine how and what specific communication interactions shape the telecommuter's perceptions of the supervisor's leadership style.

\section{REFERENCES}

Bailey, D. E. \& Kurland, N. B. (2002). A review of telework research: Findings, new directions, and lessons for the study of modern work. Journal of Organizational Behavior, 23, 383- 400.

Barge, J. K. (1994). Leadership: communication skills for organizations and groups. New York: St. Martin's Press.

Baruch, Y. (2001). The status of research on teleworking and an agenda for future research. International Journal of Management Reviews, 3,113-129.

Campbell, K. S., White, C. D., \& Johnson, D. E. (2003). Leader-member relations as a function of rapport management. Journal of Business Communication, 40, 170-194.

Cartwrite, D., \& Zander, A. (1960). Group dynamics-research and theory. Evanston, IL: Row Peterson.

Castaneda, M., \& Nahavandi, A. (1991). Link of manager behavior to supervisor performance rating and subordinate satisfaction. Group \& Organization Management, 16,357-366.

Cohen, W. M., \& Levinthal, D. A. (1990). Absorptive capacity: A new perspective on learning and innovation. Administrative Science Quarterly, 35, 128-152.

DOI:10.4236/me.2015.610104 
Cooper, C. \& Kurland, N. B. (2002). Telecommuting, professional isolation and employee development in public and private organizations. Journal of Organizational Behavior, 23, 511-532. DOI:10.1002/job.145

Deetz, S. (2001). Conceptual foundations. In F.M. Jablin \& L.L. Putnam (Eds.) The new handbook of organizational communication (pp. 3-46). London: Sage.

Demirel, H. (2014). An Investigation of the Relationship Between Job and Life Satisfaction among Teachers. Procedia Social and Behavioral Sciences, 116, 4925-4931.

Fairhurst, G. T. (1993). The leader-member exchange patterns of women leaders in industry: A discourse analysis. Communication Monographs, 60,321-351.

Feldman, D. C. \& Gainey, T. W. (1997). Patterns of telecommuting and theirconsequences: Framing the research agenda. Human Resource Management Review, 7, 369-388.

Fiedler, F. E., (1964). A contingency model of leadership effectiveness. In Advances in experimental social psychology, edited by L. Berkowitz, 149-190. New York: Academic Press.

Golden, T. D. (2006). The role of relationships in understanding telecommuter satisfaction. The Journal of Organizational Behavior, 27, 319-340. DOI: 10.1002/job.369

Gregson, T. (1991). The separate constructs of communication satisfaction and jobsatisfaction. Educational and Psychological Measurement, 51,39-48.

Hargie, O., Tourish, D., \& Wilson, N. (2002). Communication audits and the effects of increased information: A follow-up study. The Journal of Business Communication, 39, 414-436.

Hartman, H. I., Stoner, S. R., \& Arora, R. (1991). A. investigation of selected variables affecting telecommuting productivity and satisfaction. Journal of Business and Psychology, 6, 207- 225.

Hecht, M. L. (1978). The conceptualization and measurement of interpersonal communication satisfaction. Human Communication Research, 4, 253-264.

Hemphill, J. K., \& Coons, A. E. (1957). Development of the leader behavior description questionnaire. In R. M. Stogdill \& A. E. Coons (Eds.), Leader behavior: Its description and measurement (pp. 638). Columbus: The Ohio State University, Bureau of Business Research.

Holladay, S. J., \& Coombs, W. T. (1993). Communication visions: An exploration of the role of delivery in the creation of leader charisma. Management Communication Quarterly, 6, 405-427.

Kenny, D., \& Cooper, C. (2003). Introduction: Occupational stress and its management. International Journal of Stress Management, 10, 275-279.

Kiesler, S., Siegel, J., \& McGuire, T. W. (1987). Social psychological aspects of computer mediated communication. In K. Finnegan, R. Salamon, \& R. Thompson (Eds.), Information technology: Social issues (pp. 290-306). UK, Seven Oaks: Hodder and Stoughton.

Korte, W. B., \& Wynne, R. (1996). Telework: Penetration, potential and practice in Europe. Amsterdam: Ohmsha Press.

Likert, R. (1961). New patterns of management. New York: McGraw-Hill.

Locke, E. A. (1976). The Nature and Causes of Job Satisfaction. Handbook of Industrial and Organizational Psychology, edited by M. D. Dunnette (pp.1297-1349). Chicago: Rand.

Madlock, P. E. (2006). Do differences in displays of nonverbal immediacy and communicator competence between male and female supervisors affect subordinates, job satisfaction. Ohio Communication Journal, 44, 61-78.

Madlock, P. E. (2008). The link between leadership style, communicator competence, and employee satisfaction. Journal of Business Communication, 45, 61-75.

Madlock, P. E. (2010). The development of Technological Management Model: A conceptualization of computer technology in the workplace. Proceedings of the

International Association for Technology, Education, and Development. Valencia, Spain, 38, 4564-4576.

Madlock, P. E. (2012). The influence of supervisors' leadership style on telecommuters. Journal of Business Strategies, 29, 1-24. 
Madlock, P. E. (2013). The influence of motivational language in the technologically mediated realm of telecommuters. Human Resource Management Journal, 23, 196-210. doi: 10.1111/j.17488583.2012.00191.x

MarketLine (2015). Insurance in the United States. October 2017. Retrieved from https://store.marketline.com/report/ohme4735--insurance-in-the-united-states/

Mintzberg, H. (1994). Rounding out the manager's job. MIT Sloan Management Review, 36, 11- 25.

Monge, P. R., Backman, S. G., Dillard, J. P., \& Eisenburg, E. M. (1982). Communicator competence in the workplace: Model testing and scale development. Communication Yearbook, 5, 505-528.

Mowday, R. T., Steers, R. M., \& Porter, L. W. (1979). The measurement of organizational commitment. Journal of Vocational Behavior, 14, 234-247.

Mueller, B. H., \& Lee, J. (2002). Leader-member exchange and organizational communication satisfaction in multiple contexts. Journal of Business Communication, 39, 220-244.

Nadler, D., \& Tushman, M. (1988). Strategic organization design. Glenview, IL: Scott, Foresman.

Nickson, D., \& Siddons, S. (2004). Remote working-Linking people and organizations. Burlington, MA: Elsevier Butterworth-Heinemann.

Northouse, P. G. (2001). Leadership: Theory and practice (2nd ed.). Thousand Oaks, CA: Sage.

Penley, L. E., \& Hawkins, B. (1985). Studying interpersonal communication in organizations: A leadership application. Academy of Management Journal, 28, 309-328. doi:10.2307/256203

Pincus, J. D. (1986). Communication satisfaction, job satisfaction, and job performance. Human Communication Research, 12, 395-419.

Pinsonneault, A. \& Boisvert, M. (2001). The impacts of telecommuting on organizations and individuals: A review of the literature. In N. Johnson (ed.) Telecommuting and Virtual Offices: Issues and Opportunities, (pp 163-185). Hershey, PA: Idea Group Publishing.

Pondy, L. (1978). Leadership as a language game. In: M. Mccall, \& M. Lombardo(Eds) Leadership: where else can we go? (pp 87-99). Durham, NC: Duke University Press Putti, J. M.,

Aryee, S., \& Phua, J. (1990). Communication relationship satisfaction and organizational commitment. Group \& Organization Studies, 15, 44-52.

Quick, J. C., \& Macik-Frey, M. (2004). Behind the mask: Coaching through deep interpersonal communication. Consulting Psychology Journal: Practice and Research, 56, 67-74.

Rubin, R. B., Palmgreen, P., \& Sypher, H. E. (1994). Communication research measures: A sourcebook. New York: Guilford.

Russell, S. S., Spitzmüller, C., Lin, L. F., Stanton, J. M., Smith, P. C., \& Ironson, G. H.(2004). Shorter can also be better: The Abridged Job In General scale. Educational and Psychological Measurement, 64, 878-893.

Sager, J. K., \& Johnston, M. W. (1989). Antecedents and outcomes of organizational commitment: A study of salespeople. Journal of Personal Selling \& Sales Management, 9, 30-41.

Sageer, A., Rafat, S., \& Agarwal, P. (2012). Identification of Variables Affecting Employee Satisfaction and Their Impact on the Organization. Journal of Business and Management, 5, 32-39.

Shaw, L. (1996). Telecommute! To go to work without leaving home. New York: Wiley \& Sons. Spector, P. E. (1985). Measurement of Human Service Staff Satisfaction: Development of the Job Satisfaction Survey. American Journal of Community Psychology, 13, 693-713.

Spitzberg, B. H., \& Cupach, W. R. (1981, November). Self-monitoring and relational competence. Paper presented at the Speech Communication Association Convention, Anaheim, CA.

Sullivan, J. (1988). Three roles of language in motivation theory. Academy of Management Review, 13, 104-115.

Topi, H. L. (2004). Supporting telework: Obstacles and solutions. Information Systems Management, 21, 79-85.

Wang, P. \& Walumbwa, F. (2007). Family friendly programs, organizational commitment and work withdrawal: The moderating role of transformational leadership. Personnel Psychology, 60, 397-429. 
Waterhouse, J. H., \& Tiessen, P. A. (1978). A Contingency framework for management accounting systems research. Accounting, Organizations and Society, 3,65-76.

Westley, F. \& Mintzberg, H. (1991). Visionary leadership and strategic management. In J. Henry \& D. Walker (Eds.), Managing innovation (Chap. 4). London: Sage.

Wiesenfeld, B. M., Raghuram, S., \& Garud, R. (2001). Organizational identification among virtual workers: the role of need for affiliation and perceived work-based social support. Journal of Management, 27, 213-229.

World at Work (2009). Telework trendlines. February 2009. Retrieved from http://www.workingfromanywhere.org/news/Trendlines_2009.pdf.

Yukl, G. (2002). Leadership in Organizations. Englewood Cliffs, NJ, Prentice-Hall. 